\title{
Retracted: Detection of Abnormal Hemoglobin Variants by HPLC Method: Common Problems with Suggested Solutions
}

\author{
International Scholarly Research Notices \\ Received 14 April 2015; Accepted 14 April 2015 \\ Copyright (C) 2015 International Scholarly Research Notices. This is an open access article distributed under the Creative Commons \\ Attribution License, which permits unrestricted use, distribution, and reproduction in any medium, provided the original work is \\ properly cited.
}

\begin{abstract}
The paper titled "Detection of Abnormal Hemoglobin Variants by HPLC Method: Common Problems with Suggested Solutions," [1] published in International Scholarly Research Notices, has been retracted as it was submitted for publication without the knowledge and approval of one of the coauthors, Dr. Suman Lata Mendiratta. The submitting author Dr. Dipti Kalita plagiarized data from the Thalassemia Control Project headed by Dr. Suman Lata Mendiratta.
\end{abstract}

\section{References}

[1] L. Pant, D. Kalita, S. Singh et al., "Detection of abnormal hemoglobin variants by HPLC method: common problems with suggested solutions," International Scholarly Research Notices, vol. 2014, Article ID 257805, 10 pages, 2014. 